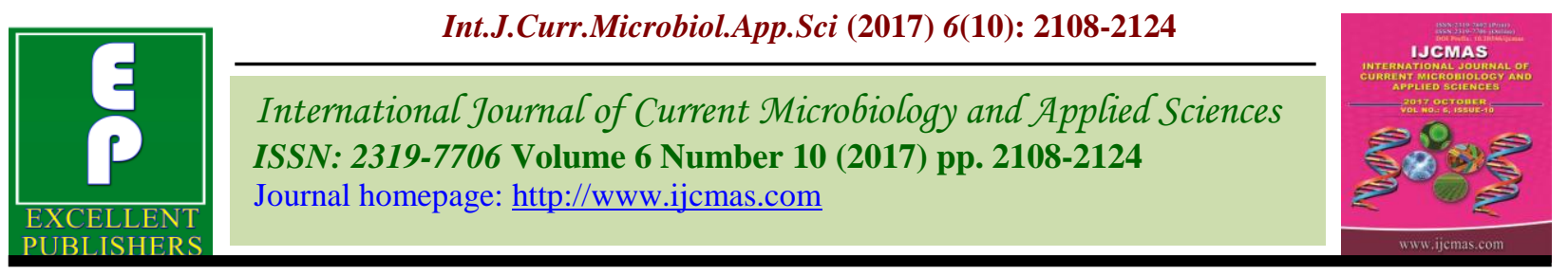

Original Research Article

https://doi.org/10.20546/ijcmas.2017.610.251

\title{
Taxonomic Studies of Leafhoppers (Hemiptera: Cicadellidae) Fauna Associated with Mango from India
}

\author{
N. Srinivasa*, N. Ramya and Naresh M. Meshram \\ Division of Entomology, ICAR- Indian Agricultural Research Institute, \\ New Delhi- 110012, India \\ *Corresponding author
}

A B S T R A C T

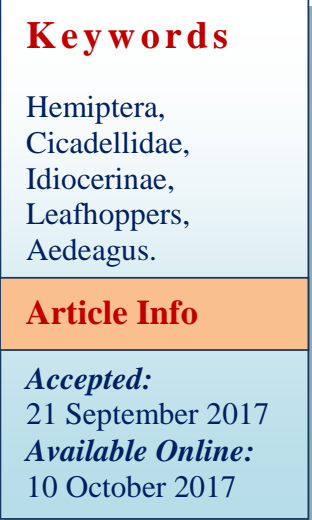

Twelve species of mango leafhoppers, Amrasca splendens Ghauri in Kerala, Amritodus atkinsoni (Lethierry) all over India, A. brevistylus Viraktamath in Karnataka and Tamilnadu, Busoniomimus manjunathi Viraktamath and Viraktamath in Kerala and Karnataka, Idioscopus clypealis (Lethierry) wide spread in India, I. anasuyae Viraktamath and Viraktamath, I. decorates Viraktamath, I. dworakowskae Viraktamath, I. jayashriae Viraktamath and Viraktamath, I. spectabilis Viraktamath all five reported from karanataka, I. nitidulus (Walker) distributed throughout India and I. nagpurensis (Walker) from Karnataka, Tamilnadu and west Bengal distributed, are redescribed with well-illustrated photographs. A key to identify leafhopper species associated with mango also provided.

\section{Introduction}

Mango infested by number of insect pests, among these leafhoppers are economically most important. Leafhoppers belong to the family Cicadellidae of the order, Hemiptera. These are small wedge shaped insects of various form, colour and size and distinguished by having one or more rows of small spines extending the length of hind tibia. The family Cicadellidae constitutes one of the largest families in the exopterygotan Hexapoda. Recent world estimates range between 35,000-45,000 species over 22,600 species are now described (Dietrich, 2004).The leafhopper species of the subfamily Idiocerinae feed and breed on trees and some are serious pests of mango, in the Indian subcontinent out of 10 genera and 43 species are recorded. Idiocerinae is a small subfamily of the Cicadellidae recognized by set of characters as follows. Head wider than pronotum, ocelli on face, facial sutures extending beyond the antennal pits almost to the ocelli, distance between antennal bases greater than that between ocelli; fore wing with wide appendix (Viraktamath, 2007).

Das et al., (1969) recorded a new species, Amrasca splendens Ghauri from Kerala on mango, Viraktamath and Viraktamath (1985) described three new species of mango 
hoppers namely, Busoniomimus manjunathi, Idioscopus anasuyae and I. jayashriae on mango in Karnataka. Nearly eighteen species of leafhoppers have been reported as pests of mango in the world (Viraktamath, 1989). Among these, five species belonging to the subfamily Idiocerinae; Idioscopus clypealis (Lethierry), I. niveosparsus (Lethierry) [now I. nitidulus (Walker)], I. nagpurensis (Pruthi), Amritodus atkinsoni (Lethierry) and Amritodus brevistylus Viraktamath are the most important leafhopper pests of mango (Viraktamath, 1989; Pena et al., 1998). Others include, Amrascas plendens, Busoniomimus manjunathi, Idioscopus decoratus, I. $d$ worakowskae and I. spectabilis which have been reported to feed on mango (Viraktamath and Viraktamath, 1995).

Collection of mango leafhoppers from major mango growing areas of India and from UAS (B) collection are studied, redescribed and well-illustrated here.

\section{Materials and Methods}

Mango leafhoppers were collected from mango orchards through sweep net and light trap from various parts of the country, were processed by series of steps like sorting, cleaning, mounting, selection of specimens for study the following characters are below
Head: Crown, Face, Compound eyes, Ocelli, Frontal suture, Subgenal suture, Clypeus.

Pronotum

Abdomen: Male genitalia: Pygofer, Subgenital plate, style, Connective, Aedeagus.

\section{Genitalia dissection}

Genitalia dissections will be carried out as described by Oman (1949) and Knight (1965). The abdomen will be removed by inserting a sharp pin between the abdomen and thorax and with gentle piercing. The abdomen will be treated in $10 \% \mathrm{KOH}$ for $2-4 \mathrm{~h}$ to remove unsclerotized material by gently prodding the abdomen with the head of a pin. Afterwards, the abdomen will be rinsed thoroughly in water. The internal structures will be then removed by a hooked pin, before being stored in glycerol vials for study. The photographs of male, female (habitus, lateral, face and thorax) and genitalia structures at different magnification were at taken with Leica DFC 425C digital camera on the Leica 19205FA stereozoomautomontage microscope. The photographs and illustrations were processed by using Adobe Photoshop CS3.

\section{Keys to species of leafhoppers associated with mango}

1. Hind tarsomere I acuminate

Amrascasplendens

- $\quad$ Hind tarsomereeI truncate 2

2. Male pygofer with trianglular projections on ventral margins Busoniomimusmanjunahi

- $\quad$ Male pygofer not as above ........................................................... 3

3. Aedeagus with elongated preatrium, shaft comparatively short $\ldots \ldots \ldots \ldots \ldots \ldots \ldots \ldots \ldots .4$

- $\quad$ Aedeagus without preatrium, shaft elongate ....................................... 5

4. Aedeagus with basal pair of spine like processes .................. Amritodusbrevistylus

- $\quad$ Aedeagus without basal pair of spine like processes ................ Amritodusatkinsoni

5. Third apical cell of fore wing with black spot, clavus yellowish green, pygofer with ventral processes, aedeagal shaft sinuate Idioscopus decoratus 


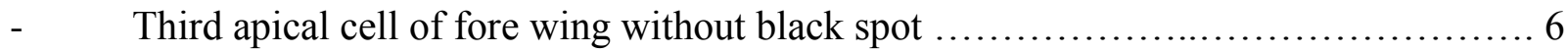

6. Face and vertex uniformly ochraceous or lemon yellow, without black irregular spots

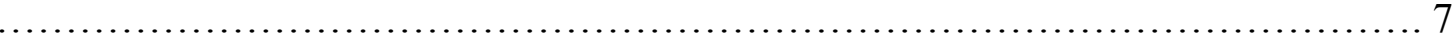

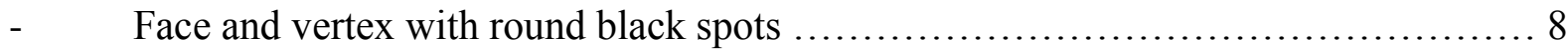

7. Head, pronotum and scutellum, yellowish green a large discal spot on pronotum and basal half of scutellum black ........................................... Idioscopus spectabilis

- Head pronotum immaculate, lemon yellow, scutellum with two dark brown basal triangular spots, anal collar processes broad, almost straight Idioscopus dworakowskae

8. Face irregularly marked with brown or black patches without well-defined black spots, style with anterior portion longer than the posterior ........................ Idioscopus nitidulus

- $\quad$ Face with one or more small round black spots near upper margin ....................... 9

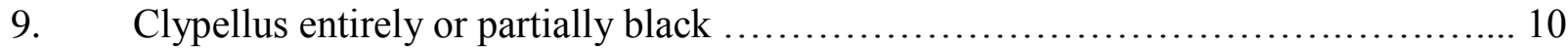

- Clypellus without any black marking .......................................... 11

10. Clypellus entirely black, apex of aedeagal shaft rather pointed, apex of style pointed Idioscopus clypealis

- Clypellus partially black, apex of aedeagal shaft knob like, apex of style broad with small round lobe Idioscopus nagpurensis

11. Aedeagus strongly sinuate, shaft broad at base narrowed and strongly curved apical hook and has pair lateral sinuate curved processes arising mid length ................................................................. Idioscopus anasuyae

- Aedeagus shaft with caudal denticle slightly before gonopore Idioscopus jayashriae

\section{Redescriptions}

Amrascasplendens Ghauri (Figure: 1, 13, 25)

Male

Brightly coloured, brown yellow deep red. Ocelli positioned on the top of the head. Face reddish anteriorly rest yellow including genae and lora. Its surrounded by yellow area.

Two round spots on anteriorly with reddish margin. Pronotum reddish medially 2 red spots on lateral margin with a small elongated white spot anteriorly on lateral margin border with a small elongated anteriorly white spot. Scutellumpiceous with equally spaced 3 white spots in triangle. Claval area light yellow ending in black patches. [Fig: 1. $(1,2), 13$. (1, 2)]

\section{Male genitalia [Fig: 25]}

Pygofer triangular in shape. Sub genital plate narrow elongated with 4 to 5 long spines laterally [Fig: 25(b)], style with broad base, tapering toward apex with spine like [Fig: 25(a)], connective $\mathrm{T}$ shape with arched base [Fig: 25(c)] and aedeagus strongly curved at apex $1 / 3$ with elongated base.

\section{Measurements (mm)}

Male 1.318 length, pronotum 0.158 length, 0.302 width, scutellum 0.162 length, 0.220 width. Crown 0.102 length and 0.378 wide across the eyes, distance between compound eye and ocelli 0.108 and 0.106 length of clypeus and distance between ocelli 0.097 . Female 1.290 length and 0.102 length of crown. 


\section{Material examined}

$1 \delta^{\lambda}$ and 19, INDIA: Karnataka: Bengaluru: GKVK: $\left(12^{\circ} 58 \mathrm{~N}, 77^{\circ} 35 \mathrm{E}, 930 \mathrm{msl}\right)$. 1. iv. 2013, at light trap, coll. Shilpa. V. A (NPC).

\section{Remark}

This species easily distinguish by the presence of acuminate first hind tarsomere from rest of the mango leafhoppers.

Amritodus atkinsoni (Lethierry) [Fig: 2, 14, 26]

Male

Yellowish brown colour, face, yellow, two prominent round black spots on anterior margin of face near to crown with brown patch between them, interrupted by small yellow line medially.

Ocelli brown in colour. Pronotum with two black somewhat triangular spots at the apex, surrounded by brown patch, laterally yellow with brown dots. Prominent brown longitudinal stripe exactly in the centre. Scutellum with two basal black triangle, coinciding with hind margin of pronotum. Two black spot in the middle with inverted V shaped mark in between. Forewing with silvery white patch in anterior margin, venation dark brown in colour. [Fig: $2(3,4)$, $14(3,4)]$.

\section{Male genitalia [Fig: 26]}

Pygofer broader than long, elongated, anal collar process well developed with anterior basal fracture [Fig: 26(h)]. Subgenital plate narrow, with numerous fine setae throughout [Fig: 26(g)].

Connective $\mathrm{T}$ shape with bilobedstem [Fig: 26(i)]. Style elongated, curved apically, fine prominent setae at the apex, 9-10 spine like setae on anterior 1/3 [Fig: 26(f)]. Aedeagus S shaped, spine-like processes absent, preatrium at the middle, elongated, shorter than the shaft [Fig:26(e)] and valve[Fig:26(j)].

\section{Measurements (mm)}

Male 4.713 length, pronotum 0.591 length, 1.505 width, scutellum 0.904 length, 1.208 width.

Crown 0.226 , length and 1.748 wide across the eyes, distance between compound eye and ocelli 0.191 and 0.412 length of clypeus and distance between ocelli 0.471 .

Female 4.685 length and 0.224 length of crown.

\section{Material examined}

$5{ }^{\lambda}$ and 7 , INDIA: IARI: New Delhi: $\left(28.0800^{\circ} \mathrm{N}, 77.77 .1200^{\circ} \mathrm{E}, 228.61 \mathrm{msl}\right)$, 09.vi.2014, mango orchard, coll. Srinivas (NPC), Karnataka: Kolar: Abbenahalli: $10 \curvearrowright$ and 13 q, $\left(13.0374495^{\circ} \mathrm{N}, 77.9424531^{\circ} \mathrm{E}\right)$, 15.v.14, mango orchard, coll. Srinivas (NPC).

\section{Remark}

Amritodus atkinsoni is similar to $A$. brevistylus in coloration but differs in aedeagus without pair of prominent spine at base of shaft.

Amritodes brevistylus Viraktamath [Plate Fig: 3, 15, 27]

\section{Male}

Light brown in colour, face with two prominent black spots anteriorly on the face or near to crown, with dark brown patch interrupted by yellow line medially with sculpturing. Ocelli dark brown in colour, base of the antennae surrounded by black spot and genae yellow. Pronotum anteriorly with two black dots with brown margin. Lateral margin 
yellow with prominent narrow brown patch in centre. Scutellum with two basal triangle with two spots medially on each side. Forewing with silvery white patch in anterior margin, venation dark brown in colour. [Fig: $3(5,6)$, $15(5,6)]$.

\section{Male genitalia [Fig: 27]}

Pygofer elongated, anal collar process well developed with basal fracture [Fig: 27(n)]. Subgenital plate narrow with numerous setae throughout [Fig: 27(m)]. Connective T shaped with basebilobed [Fig: 27(o)].

Style elongated and broad basally and medially with curved apically, fine prominent setae at apex, 10-20 setae on anterior 1/3[Fig: 27(1)]. Aedeagus S shaped with elongated preatrium in middle shorter than shaft with a pair prominent spine at the base of shaft [Fig: 27(k)] and valve [Fig: 27(p)].

\section{Measurements (mm)}

Male 2.320 length, pronotum 0.309 length, 0.746 width, scutellum 0.494 length, 0.583 width.

Crown 0.104 length and 0.908 wide across the eyes, distance between compound eye and ocelli 0.103 and 0.189 length of clypeus and distance between ocelli 0.240. Female 2.264 length and 0.136 length of crown.

\section{Material examined}

$2 \widehat{\gamma}$ and $2 q$, INDIA: Karnataka: Bengaluru: Hebbal: $\left(13.0400^{\circ} \mathrm{N}, 77.5900^{\circ} \mathrm{E}, 920 \mathrm{msl}\right)$ 27.x.2011, light trap, coll. Sudha (NPC).

\section{Remark}

Amritodusbrevistylus closely resemble $A$. atkinsoni in colouration and in general characters but differ in having a pair of prominent spine at the base of shaft.

\section{Busoniomimusm anjunathi Viraktamath \& Viraktamath [Fig: 4, 16, 28] \\ Male}

Ochraceous yellow, face yellow, two round black spots anteriorly.

Ocelli surrounded by dark brown, eyes whitetish grey and laterally dark brown. Pronotumshahgreen without any spots, scutellum with two oval spots on disc and two triangular spots anteriorly. Forewing basal 2/3 ${ }^{\text {rd }}$ costa brown [Fig: $\left.4(7,8), 16(7.8)\right]$.

\section{Male genitalia [Fig: 28]}

Pygofer elongated, anal collar process well developed. Caudally pointed with triangular projections in the ventral margin, basal fracture absent [Fig: 28(e)]. Male plate thin, widened distally and ventral long hair like setae at the distal $2 x$ the length of the plate [Fig: 28(c)].

Connective longer than wide [Fig: 28(d)]. Style robust, wider in middle and acute apically with stouter setae in the dorsal margin, 2 small rows of setae at the base of aphophysis [Fig: 28(b)]. Aedeaugus Y shaped basal strut, dorsal apodeme stout on the middle of aedeagus. Shaft pointed apically with $1 / 3^{\text {rd }}$ lightly serrated; a pair of processes arise at base of shaft. [Fig: 28(a)] and valve [Fig: 28(f)]..

\section{Measurements (mm)}

Male 4.366 length, pronotum 0.476 length and 1.390 width, scutellum 0.810 length and 1.077 width, crown 0.127 long and wide across the eyes 1.611. Distance between compound eyes and ocelli 0.248 and length of clypeus 0.327 and distance between ocelli 0.364. Female 4.568 length and crown length 0.143 . 


\section{Material examined}

$10^{\lambda}$ and 1ㅇ, INDIA: Karnataka: Siddapura: Unchalli falls: $\left(14^{\circ} 24^{\prime} 34^{\prime \prime} \mathrm{N} 74^{\circ} 44^{\prime} 51^{\prime \prime} \mathrm{E}, 590\right.$ msl), 26. vi. 2010, Sweep net, coll. Yeshwanth (NPC).

\section{Remarks}

Busoniomimusm anjunathi is nearer to $B$. setulistylus but differ in aedeagal shaft with pair of basal processes.

Idioscopus anasuyae Viraktamath and Viraktamath [Fig: 5, 17, 29]

Male

Shahgreen colour, face yellow, two large black spots on upper part of the face and visible partially dorsally, ocelli yellow and eyes are dark brown. Clypellus full yellow. Pronotum brown without any spot. Scutellum lateral margin and posterior half yellow. Fore wing brownish with fusious apical area [Fig: $5(9,10), 17(9,10)]$.

\section{Male genitalia [Fig: 29]}

Pygofer longer than breadth and heavily pigmented caudally, anal collar process well developed [Fig: 29(k)]. Subgenital plate membranous, wider at the $1 / 3^{\text {rd }}$ length of the area, with long hair like setae [Fig: 29(i)]. Connective $\mathrm{T}$ shape with peg at base [Fig: 29(j)].

Style strongly curved, apophysis long and ventrally crenulated with sub apical tooth and marginal setae. Apophysis broadened basally, narrowed in middle with narrowed apex [Fig: 29(h)]. Aedeagus sinuate with well-developed dorsal apodeme, shaft broadened basally, narrowed and strongly curved dorsally hooked apically with has a pair of lateral sinuate curved process arising medially on shaft [Fig: 29(g)].

\section{Measurements (mm)}

Male 3.4 length, pronotum 0.4 length and 1.1 width, scutellum 0.6 and 0.8 in length and width crown 0.2 length and 1.3 wide across the eyes. Distance between the compound eye and ocelli 0.2 and length of the clypeus 0.2 . Distance between the ocellus 0.4. Female 3.6 in length and 0.1 length of the crown.

\section{Materials examined}

Paratype $10^{\lambda}$ and 1 , INDIA: Karnataka: Mangalore: $\left(12^{\circ} 52^{\prime} \mathrm{N} 74^{\circ} 53^{\prime} \mathrm{E}, 22 \mathrm{msl}\right)$, 13.i.1984, coll. Shashidhar (NPC).

\section{Remark}

Idioscopus anasuyae closely resembles $I$. dworakowskae and I. spectabilis but differ in having processus on aedeagal shaft.

Idioscopus clypealis (Lethierry) [Fig: 6, 18, 30]

\section{Male}

Yellowish, face yellow colour. Two prominent round black spots apex of face or near to crown area between them and above the ocelli covered by brown patch, ocelli brown in colour. Whole clypeus dark black in colour. Pronotum without a spot lemon yellow in colour. Scutellum with two basal dark triangle with two small dark spots in between and with deep yellow at the apex [Fig: $6(11,12), 18(11,12)]$.

\section{Male genitalia [Fig: 30]}

Pygofer elongate, longer than broad with anterior basal fracture, collar spine well developed [Fig: 30(p)]. Sub genital plate elongated with setae at ventradapex [Fig: 30(o)]. Connective T shape with basal stem trilobed and laterally expanded at apex, basal 
lateral area pigmented [Fig: 30(q)]. Style sickle shape with few spine like structure at apex [Fig: 30(n)]. Aedeagus with basal apodeme extending $1 / 3^{\text {rd }}$ of the shaft, apically with 2 pair equal processes, inner pair is short, more than half as long as longer pair [Fig: 30(m)] and valve [Fig: 30(r)].

\section{Measurements (mm)}

Male 1.9 length, pronotum 0.2 length, 0.6 width, scutellum 0.3 length, 0.4 width. Crown 0.1 length and 0.7 wide across the eyes, distance between compound eye and ocelli 0.1 and 0.2 length of clypeus and distance between ocelli 0.2 . Female 2.0 length and 0.2 length of crown.

\section{Materials examined}

$5 \hat{\circ}$ and 89 , INDIA: Tamilnadu: Thandikudi: $\left(10^{\circ} 18^{\prime} \mathrm{N}, 77^{\circ} 38^{\prime} \mathrm{E}, 1300 \mathrm{msl}\right), 19 . v .2010$, Orange. coll. A.N. Reddy (NPC).

\section{Remarks}

Idioscopus clypealis is externally similar to $I$. nagpurensis, but differ in clypeus coloration and apex of aedeagal shaft pointed.

Idioscopus decoratus Viraktamath [Fig: 7, 19, 31]

Male

Shah green to parrot green in colour, two prominent round black spots apex of face or near to crown, area between them and above the ocelli covered by irregular stikings or sculpture. Face yellow in colour, eye with lateral spot, ocelli yellow in colour. Pronotum well decorated with parrot green, without a spot, scutellum with two basal small two black triangle, rest dark yellow. Clavus with deep yellow. In wing the region above the appendix with black spot [Fig: $7(13,14) 19$ $(13,14)]$.

\section{Male genitalia [Fig: 31]}

Pygofer with ventral processes elongated, anal collor process well developed [Fig: 31(d)]. Subgenital plate less pigmented, sparse setae [Fig: 31(c)]. Connective exactly T shape with broad base [Fig: 31(f)]. Style strongly arched 3 times length of base of style, narrowed in middle, broad in both end with small bunch of setae in middle with prominent spine like setae at apex in caudal view [Fig: 31(b)]. Aedeagus shaft sinuate with basal apodeme stout, preatrium elongated, shaft tapering towards the end with inverted S shape [Fig: 31(a)] and valve [Fig: 31(e)].

\section{Measurements (mm)}

Male 1.5 length, pronotum 0.2 length, 0.3 width, scutellum 0.2 length, 0.3 width. Crown 0.1 length and 0.6 wide across the eyes, distance between compound eye and ocelli 0.1 and 0.2 length of clypeus and distance between ocelli 0.2. Female 1.4 length and 0.1 length of crown.

\section{Material examined}

1ิ and 1ㅇ, INDIA: Karnataka: Sirsi: Unchalli falls: $\left(14.62^{\circ} \mathrm{N}, 74.85^{\circ} \mathrm{E}, 590 \mathrm{msl}\right)$, 24.v.2010, at light, coll. Yeshwanth. H. M (NPC).

\section{Remark}

I. decoratus similar to I. spectabilis but differs in having third apical cell of forewing with black spot and clavus yellowish green

\section{Idioscopus dworakowskae Viraktamath [Fig: 8, 20, 32]}

\section{Male}

Light brown. Face with two prominent black spots apex of face or near to crown, ocelli 
yellow in colour. Eyes dark grey with lateral black spot, whole face light yellowish without patches. Pronotumshahgreen or lemonyellow, immaculate, two big triangular spots at the base of scutellum, area between them and anterior to median impressed line brown [Fig: $8(15,16), 20(15,16)]$.

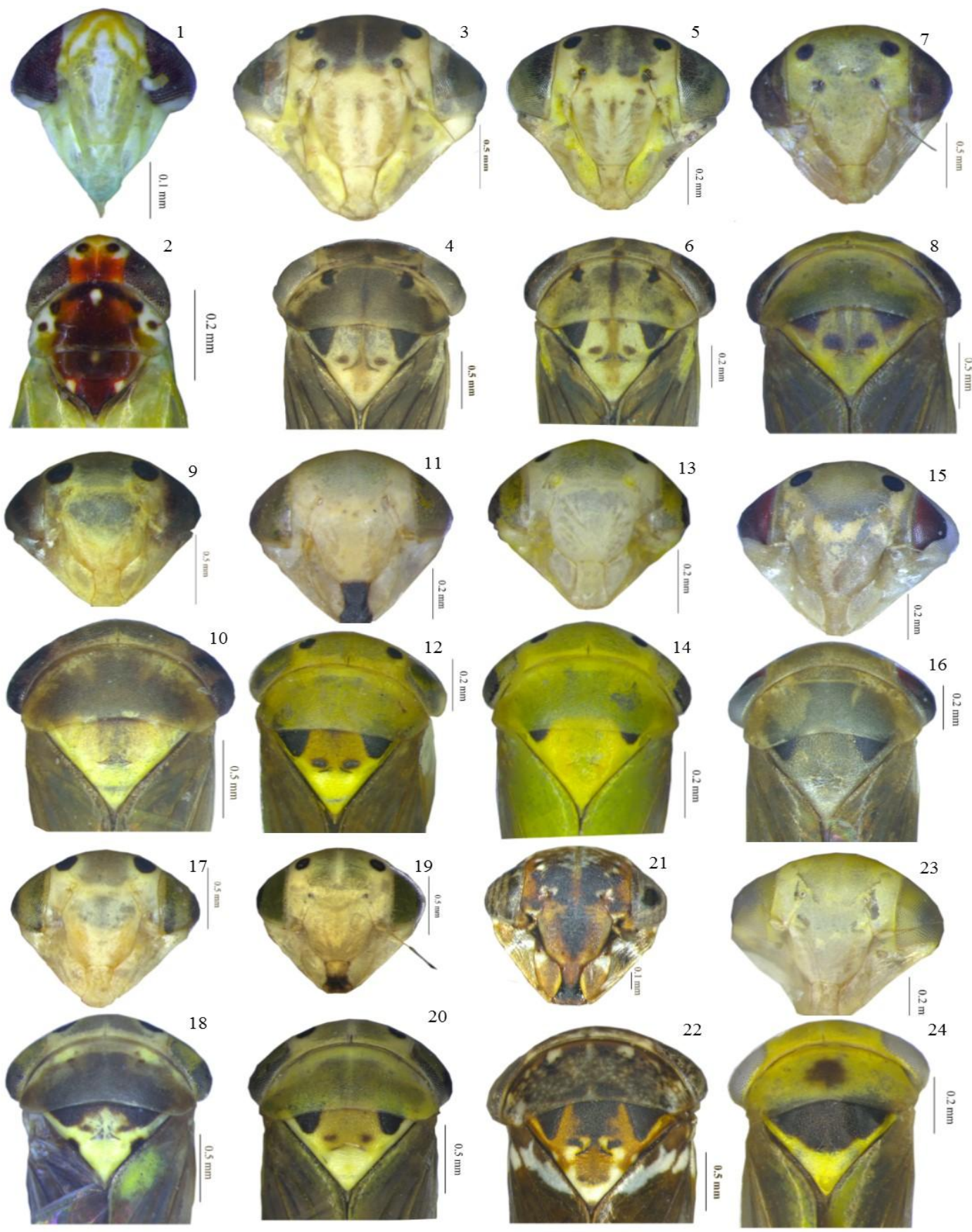

Fig-1 to 12. Face and Pronotum:1 A mrasca splendens Ghauri(1,2), 2. Amritodus atkinsonii ((Lethierry)(3,4), 3. A. brevistylus Viraktamath $(5,6), 4$. Busoniomimus mamjunathi Virakta math \& Viraktamath( 7,8$), 5$. Idioscopus anasuyae Viraktamath and Viraktamath $(9,10), 6.1$. clypealis (Lethierry)(11.12), 7. I. decoratus Viraktamath,(13,14), 8. I. dworakowskae Viraktamath $(15,16)$ 9. I. jayashriae Viraktamath and Viraktamath $(17,18), 10$. I. nagpurensis (Pruthi) $(19,20), 11$.. I. nitidulus (Walker)(21,22), 12. I. spectabilis Viraktamathi $(23,24)$ 


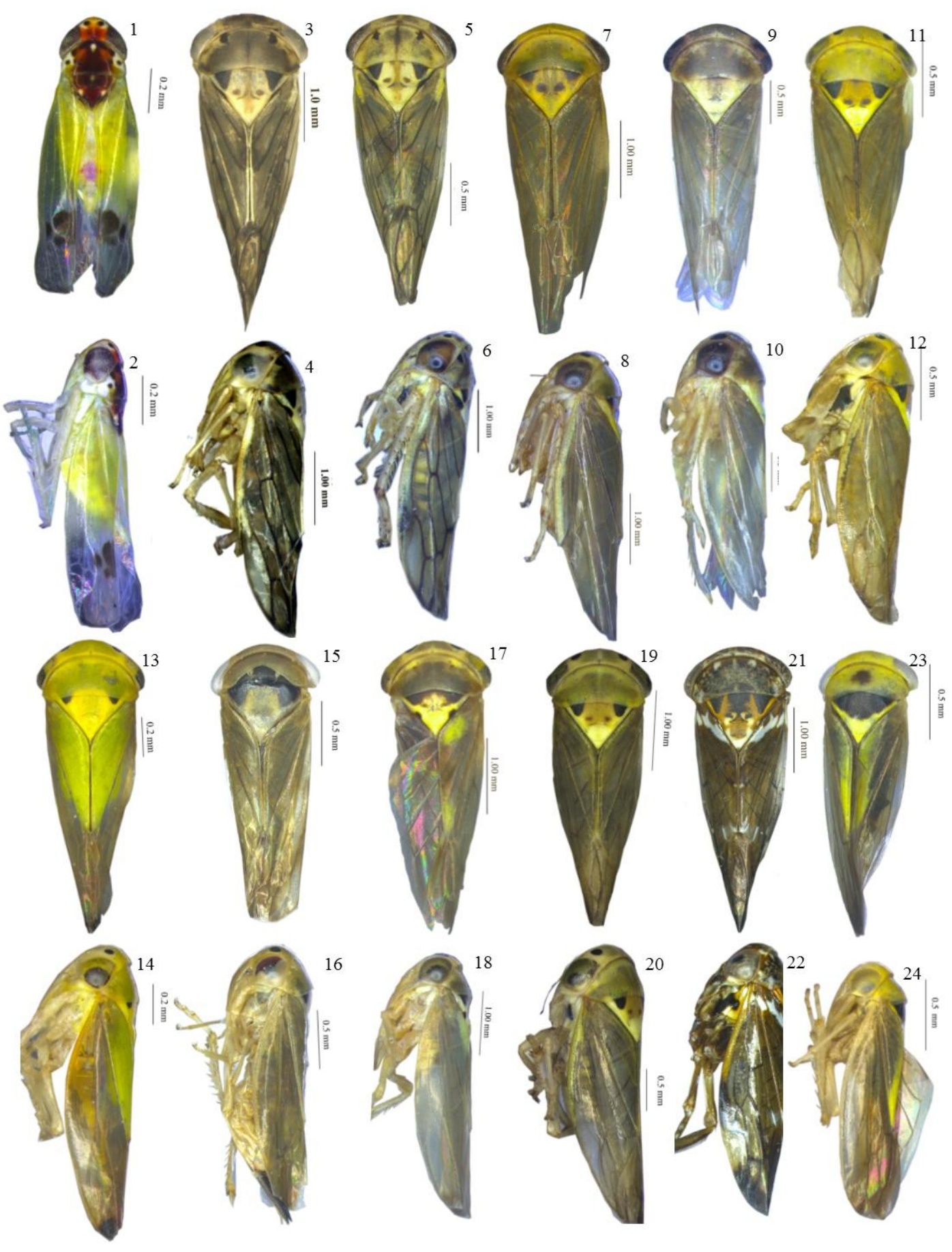

Fig-13 to 24. Male habitus:13. A mrasca splendens Ghauri(1,2), 14. A mritodus atkinsonii ((Lethierry)(3,4), 15. A. brevistylus Viraktamath $(5,6), 16$. Busoniomimus manjunathi Viraktamath \& Viraktamath $(7,8), 17$. Idioscopus anasuyae Viraktamath and Viraktamath(9.10), 18. I. clypealis (Lethierry)(11,12), 19. I. decoratus Viraktamath(13,14), 20. I. dworakowskae Viraktamath(15,16), 21. I. jayashriae Viraktamath and Viraktamath(17,18), 22. I. nagpurensis (Pruthi) $(19,20), 23$. I. nitidulus (Walker)(21,22), 24. I. spectabilis Viraktamath $(23,24)$. 

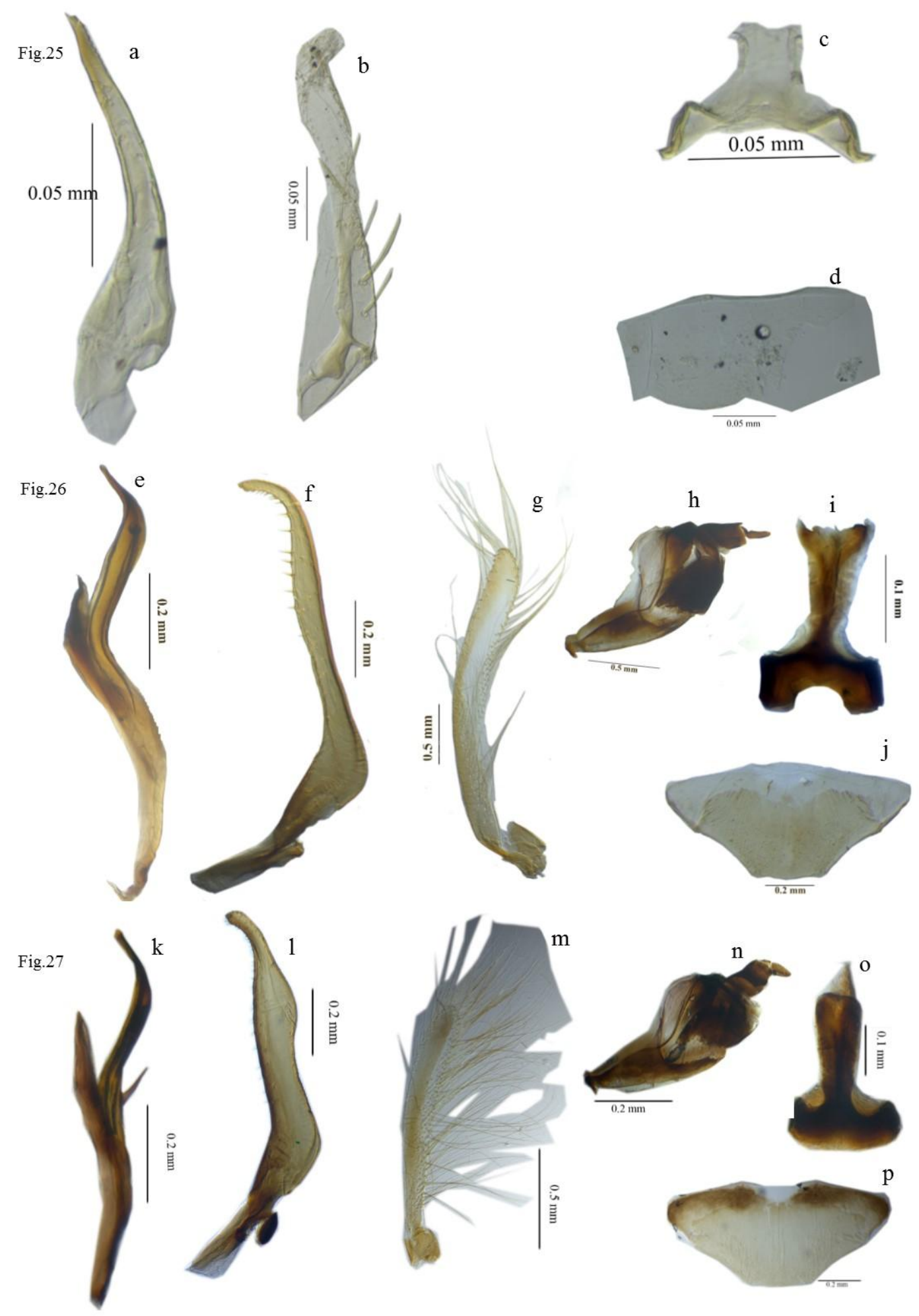

Fig-25 to 27. Male genitalia:25. A mrasca splendens Ghauri (a-d), 26. A mritodus atkinsonii (Lethierry) (f-j), 27. A. brevistylus Viraktamath(k-p). 

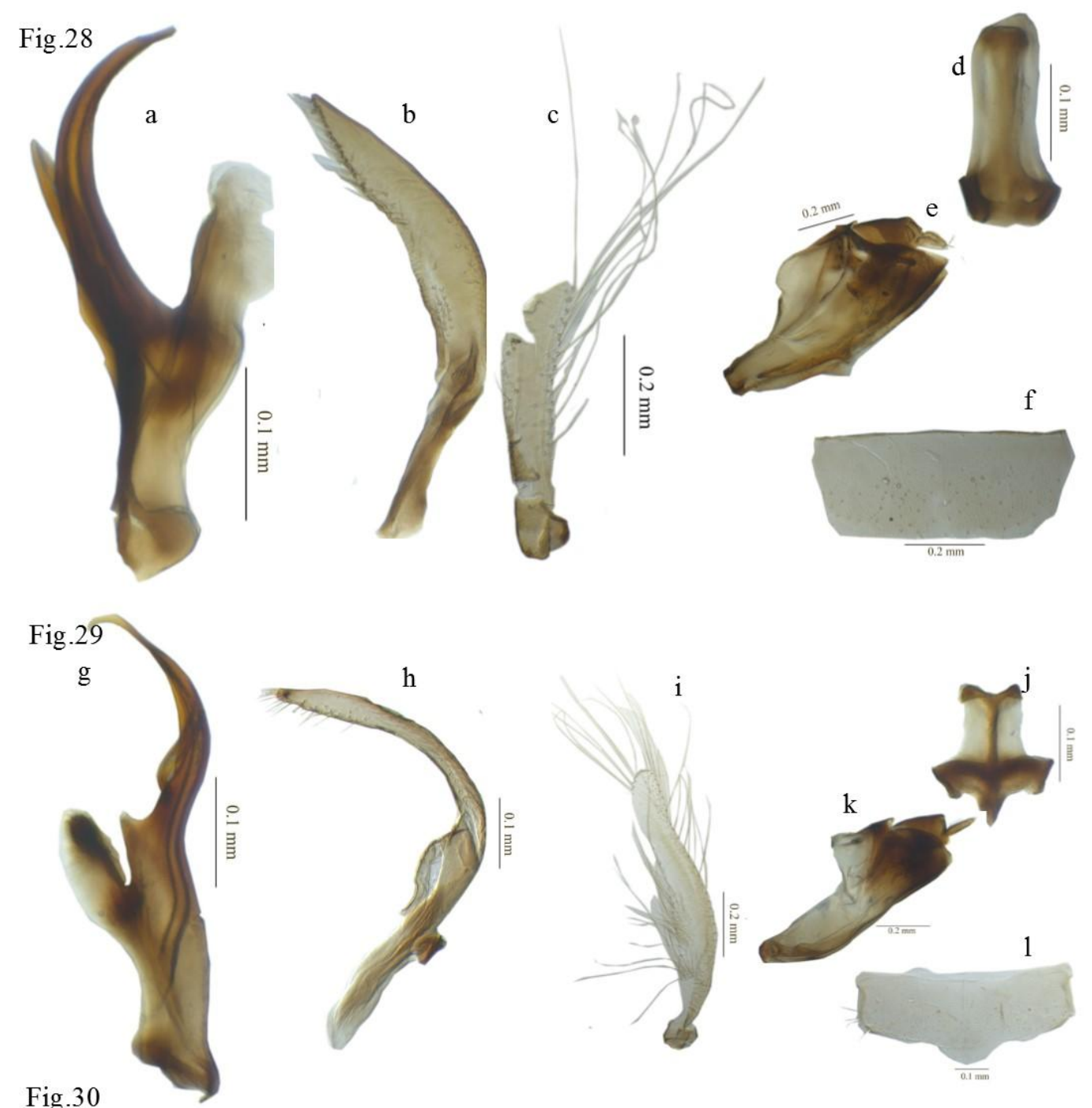

Fig.30

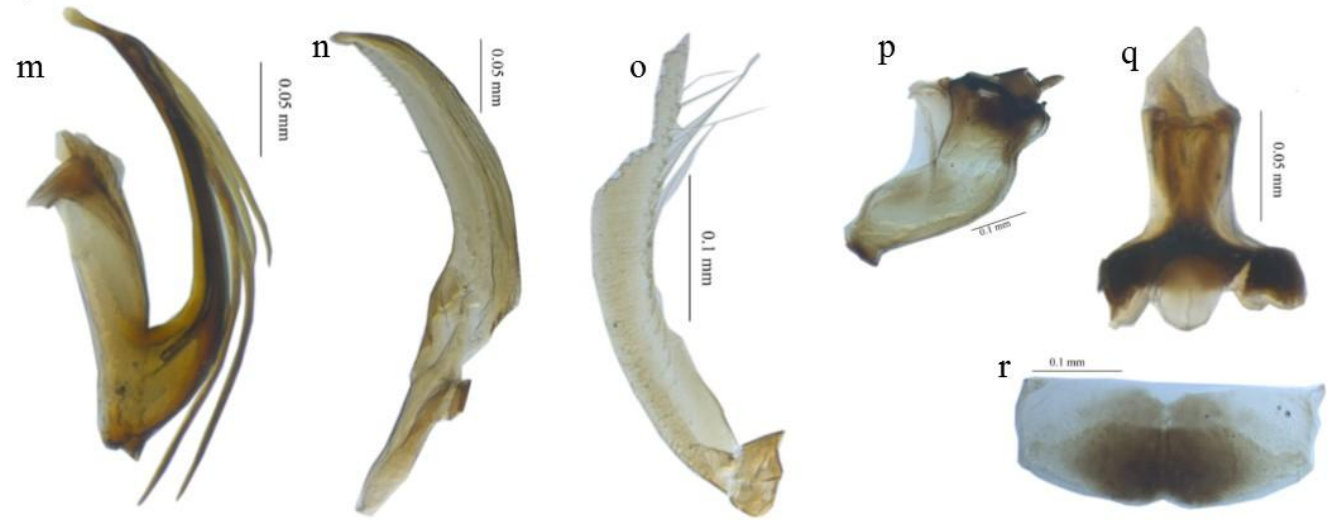

Fig.28,29,30 : Male genitala. 28. Busoniomimus manjunathi Viraktamath \& Viraktamath(a-f), 29. Idioscopus cnasuyce Viraktamath and Viraktamath(g-1), 30. I. clypealis (Lethierry)(m-r). 

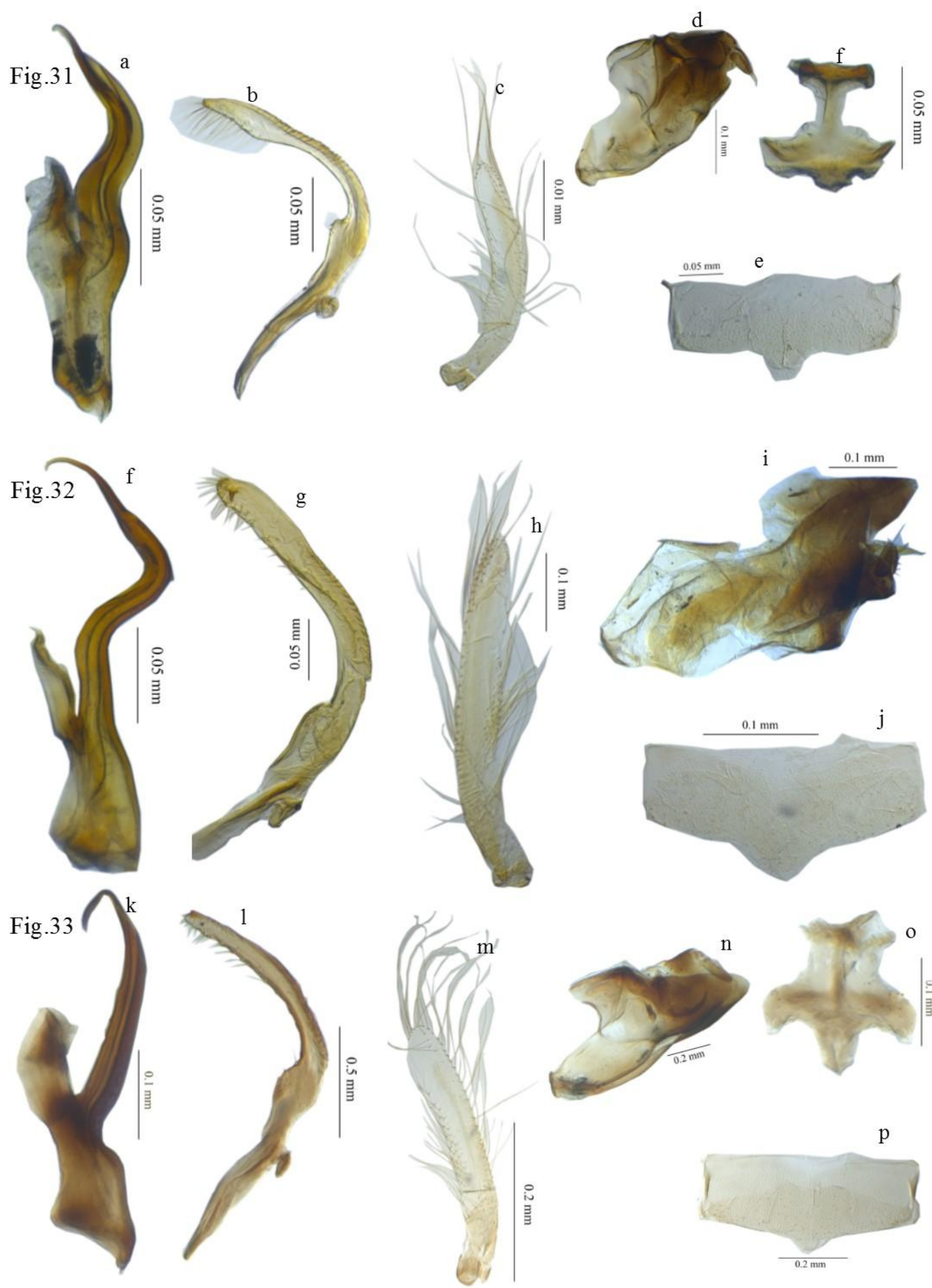

Fig.31,32,33. Male genitalia: 31. I. decoratus Viraktamath(a-e), 32. I. dwordkowskae Viraktamath(f-j), 33. I. jay ashrice Viraktamath and Viraktamath(k-p), 

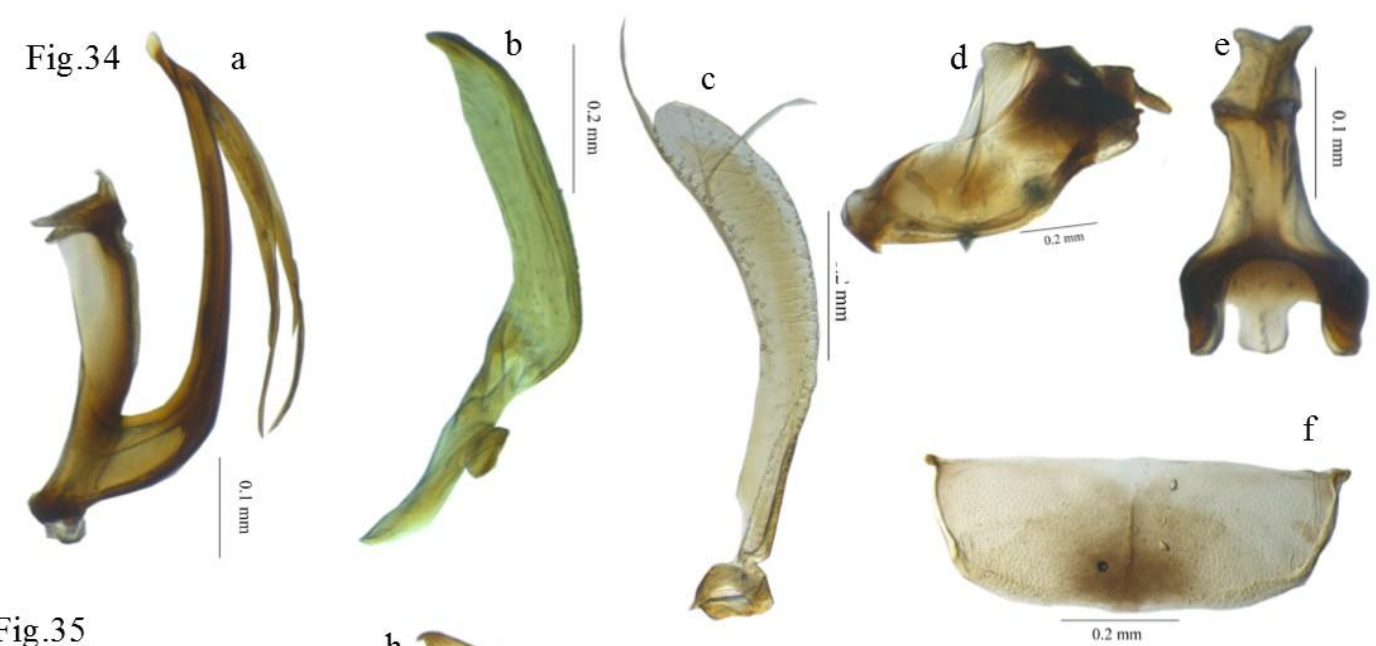

Fig. 35
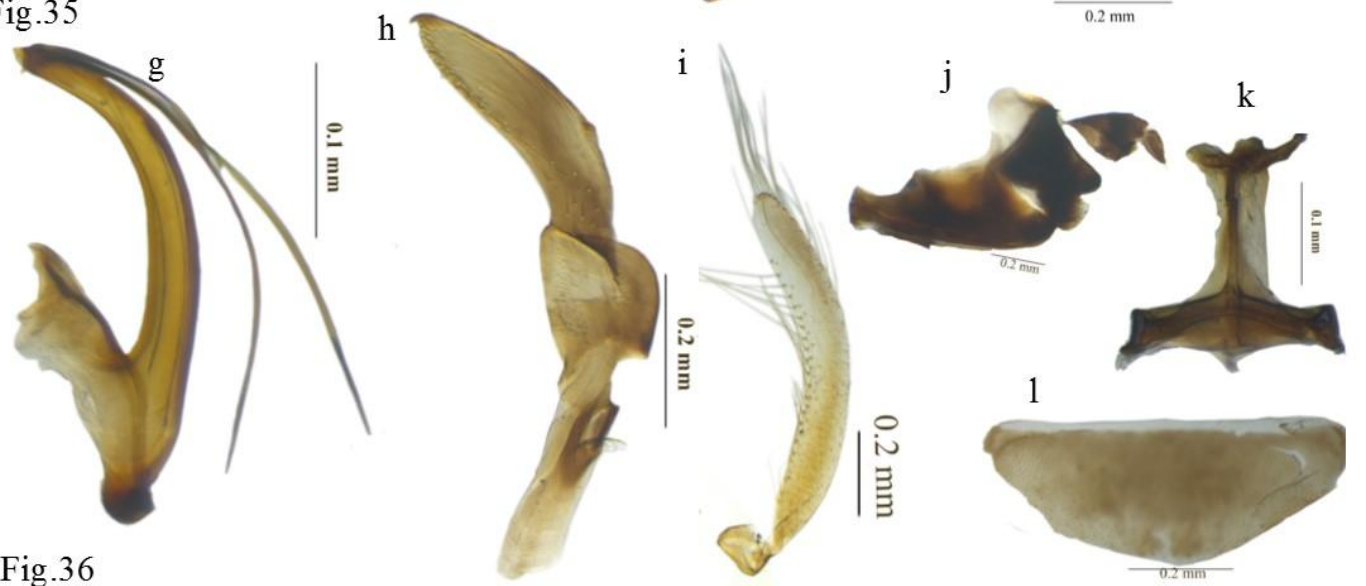

Fig. 36

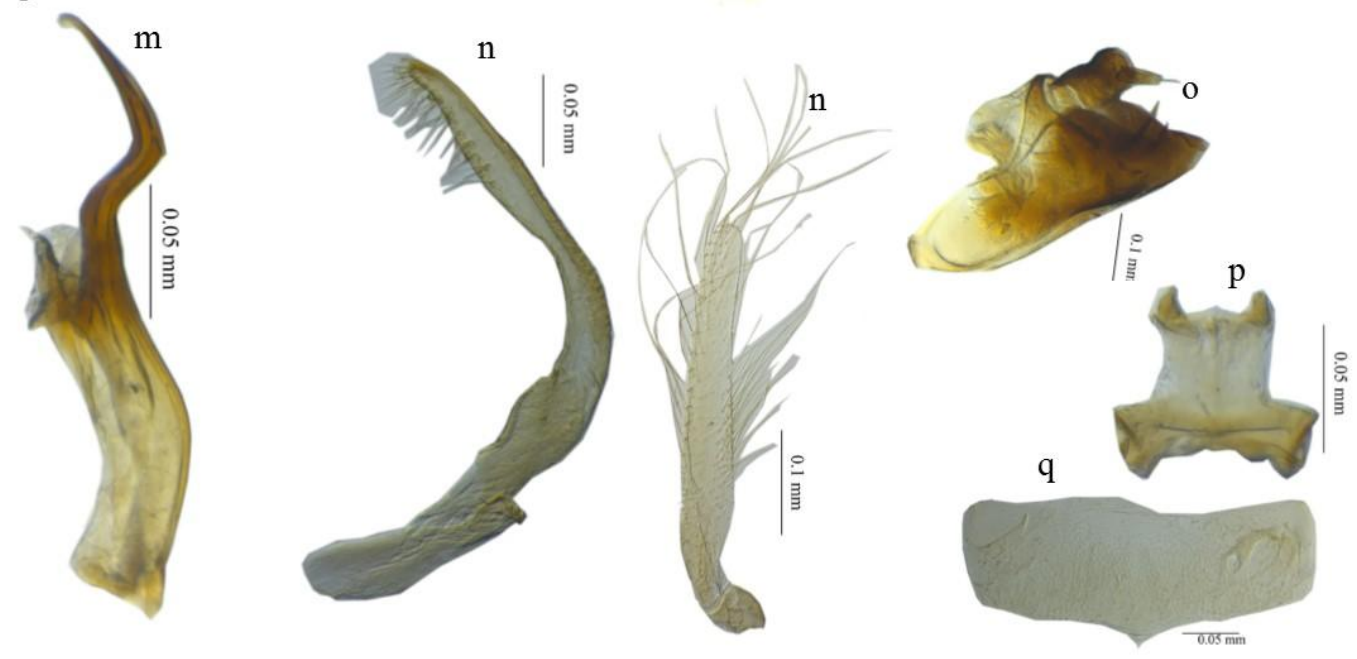

Fig.34,35,36. Male genitalia: 33. I. nagpurensis (Pruthi)(a-f), 34.. I. nitidulus (Walker)(g-1), 35. I. spectabilis Viraktamath (m-q). 
Male genitalia [Fig: 32]

Pygofer elongated with well developed apodemes, as well as anal collar processes [Fig: 32(i)]. Subgenital plate narrow with sparse setae [Fig: 32(h)]. Style elongated, laterally curved, prominent setae at apex with apical tooth strong and well developed [Fig: 32(g)]. Aedeagus with well-developed dorsal apodeme, shaft strongly curved caudally and then antero- dorsally will give hook like shape [Fig: 32(f)] and valve [Fig: 32(j)].

\section{Measurements (mm)}

Male 2.1 length, pronotum 0.2 length, 0.6 width, scutellum 0.5 length, 0.6 width. Crown 0.1 length and $0.7 \mathrm{~mm}$ wide across the eyes, distance between compound eye and ocelli $0.1 \mathrm{~mm}$ and 0.2 length of clypeus and distance between ocelli 0.2. Female 2.4 length and 0.1 length of crown.

\section{Material examined}

1 $\delta^{\lambda}$ and 19, INDIA: Karnataka: Coorg: Makuta: (12 $\left.{ }^{\circ} 04^{\prime} \mathrm{N}, 7^{\circ} .43^{\prime} \mathrm{E}, 907 \mathrm{msl}\right)$, 05.v.2005, Vateriaindica. coll. V.B. Srinivas (NPC).

\section{Remarks}

I. dworakowskae closely resemble I. clypealis but differ in aedeagal structure and also absence of black spots on crown.

Idioscopus jayashriae Viraktamath and Viraktamath [Fig: 9, 21, 33]

Male

Golden to bright yellow, head grayish, face ochraceous, without any spots, two prominent black spots on upper part of the face and partially visible dorsally.
Ocelli yellow, compound eyes grayish with golden stripes. Clypellus yellow, pronotum brown without spots, scutellumochraceous basally, greenish yellow laterally and apically and two basal black triangle and two semicircullar marginal spots or shots.

Clavus yellowish green. Fore wing infuscated apically [Fig: $9(17,18), 21(17,18)]$.

\section{Male genitalia [Fig: 33]}

Pygofer elongated, with prominent anal collar process, no basal fracture [Fig: 33(n)]. Subgenital plate wider, from dorsal half to apex long hair like marginal setae, ventral from base to $3 / 4^{\text {th }}$ of apex with small hair like setae [Fig: 33(m)]. Connective as long as wide peg medially [Fig: 33(o)]. Style strongly arched, apophysis almost twice as long as the anterior part articulation with connective, apophysis with many subapical spine like setae. [Fig: 33(j)].

Aedeagus with basal strut, dorsal apodeme well developed, Y- shaped shaft slender caudally directed with caudal denticle slightly before gonopore, shaft beyond gonopore attenuated (weakened) and strong anteriorly curved [Fig: 33(k)] and valve [Fig: 33(p)].

\section{Measurements (mm)}

Male 3.8 length, pronotum 0.5 length, 1.3 width, scutellum 0.7 length and 0.9 width. Crown 0.2 length and $1.5 \mathrm{~mm}$ wide across the eyes, distance between the compound eye and ocelli 0.2 and length of the clypeus 0.4 . Distance between the ocelli 0.4. Female 4.7 length and 0.1 length of the crown.

\section{Materials examined}

Paratype: $1 \delta^{\lambda}$ and 19 , INDIA: Karnataka: Mangaluru: $\left(12^{\circ} 52^{\prime} \mathrm{N} 74^{\circ}\right.$ 53' E, 22msl), 12.i.1984, coll. Shashidhar (NPC). 


\section{Remark}

I. jayashriae look alike I. spectabilis and I. $d$ worakowskae but differ in having tip of the aedeagal shaft attenuated and two black spots on scutellum.

Idioscopus nagpurensis (Pruthi) [Fig: 10, 22, 34]

\section{Male}

Lemon yellow to brown in colour. Face lemon yellow, eyes green with lateral black markings. Two round spots on the head visible dorsally and ventrally, area above the face/crown with lateral stripes. Clypeus basal half black, half yellow. Scutellum with two basal black triangle spot and two small brown dots in between them. Pronotum yellowish. Fore wing bronzy brown, costal yellow with small row of pits [Fig: $10(19,20), 22$ (19, 20)].

\section{Male genitalia [Fig: 34]}

Pygofer elongate with basal fracture, ventrad distal end with small spine like process [Fig: 34(d)]. Subgenital plate narrowed half basal length and above broadened, inner lateral margin region bearing long setae from middle extending to apex [Fig: 34(c)].

Connective short, $\mathrm{T}$ shaped with bilobed arms [Fig: 34(e)]. Style, robust with blunt apex and hair like fine setae on lateral margin [Fig: 34(b)].

Aedeagus with well-developed basal apodeme, aedagal shaft tapering caudally from base to slightly knobbed apex, apex with two pairs of subequal processes with serrations basally, one pair reaching base aedeagus and another pair extended up to half aedeagus [Fig: 34(a)] and valve [Fig:34(f)].

\section{Measurements (mm)}

Male 3.6, pronotum 0.5 length, 1.3 width, scutellum 0.7 length and 0.9 width. Crown 0.2 length and wide across the compound eyes is 1.2 length. Distance between the eye and ocelli 0.2 , length of clypeus 0.2 and distance between Ocelli 0.4. Female 3.6 and 0.1 length of crown.

\section{Material examined}

9 $\widehat{\partial}$ and 13, INDIA: IARI: New Delhi: $\left(28.0800^{\circ} \mathrm{N}, 77.77 .1200^{\circ} \mathrm{E}, 228.61 \mathrm{msl}\right)$, 09.vi. 2014, mango orchard, coll. Srinivas (NPC), Jharkhand: Ranchi: $25 \overbrace{}^{\lambda}$ and $28 q$ $\left(23^{\circ} 37^{\prime} 3^{\prime \prime} \mathrm{N}\right.$, and 86 $6^{\circ} 30^{\prime \prime} \mathrm{E}$ and $\left.651 \mathrm{msl}\right)$, 09,v, 2014, mango orchard, light trap, Naresh M. Meshram, Karnataka: Kolar: Abbenahalli: $120^{\wedge}$ and 23 q $\left(13.0374495^{\circ} \mathrm{N}\right.$, 77.9424531 $\left.{ }^{\circ} \mathrm{E}\right), 15 . \mathrm{v} .14$, mango orchard, coll. Srinivas (NPC), Medahatti: $19{ }^{\top}$ and 21 , $\left(13^{\circ} 43^{\prime} 60 \mathrm{~N}, 75^{\circ} 19^{\prime} 60 \mathrm{E}\right.$ and $\left.600 \mathrm{msl}\right)$, mango orchard, coll. Srinivas (NPC).

\section{Remarks}

Idioscopus nagpurensis is externally similar to Idioscopus clypealis, but differ in clypeus coloration and processes of aedeagus.

Idioscopus nitidulus (Walker) [Fig: 11, 23, 35]

\section{Male}

Dark brown in colour. Face, dark brown, irregular black marking's with white spots. Genae with silvery stripe in the middle, area above ocelii with transerve stripes. Pronotum with diffused dark brown or black markings with irregular pattern. Scutellum with two basal black triangle spot and a median spot between them with two small irregular spot on each side. Compound eye brown with thin longitudinal line and ocelii dark brown. Fore wing with oblique white mark at the base and 
obscure white mark at apex of clavus [Fig: 11 $(21,22), 23(21,22)]$.

\section{Male genitalia [Fig: 35]}

Pygofer elongatewith an anterior basal fracture [Fig: 35(j)]. Subgenital plate elongate, broder at the base, narrower towards apex, long hair like setae started in the $1 / 3^{\text {rd }}$ and reaching to apex in dorsal surface. Long hair like setae at the apex crowded and extended up to ventral surface at the apex with short setae [Fig: 35(i)].

Connective $\mathrm{T}$ shape in dorsal with lateral expanded hyaline or thin sheet like structure [Fig: 35(k)]. Style sickle shaped, broad at the base and narrowed apically leads to spine like apex [Fig: 35(h)]. Aedeagus rounded apically, with basal apodeme well developed reaching half of length to aedagus, apex with two pairs of small filamentous unequal processes, small pair reaching up to 0.33 length of aedeagus, another pair extended up to base of the aedeagus [Fig: 35(g)] and valve [Fig: 35(1)].

\section{Measurements (mm)}

Male 4.4 length, Pronotum 0.5 length, 1.5 width, Scutellum 0.9 length and 1.2 width, crown 0.1 long and wide across the compound eyes1.70. Distance between compound eye and ocelli 0.2 and length of clypeus 0.4 and distance between ocelli 0.4 . Female 6.5 length and 0.5 length of the crown.

\section{Material examined}

$11 \delta^{\lambda}$ and 23 , INDIA: IARI: New Delhi: $\left(28.0800^{\circ} \mathrm{N}, 77.77 .1200^{\circ} \mathrm{E}, 228.61 \mathrm{msl}\right)$, 09.vi. 2014, mango orchard, coll. Srinivas (NPC), Karnataka: Kolar: Abbenahalli: 320 and $43 \circ,\left(13.0374495^{\circ} \mathrm{N}, 77.9424531^{\circ} \mathrm{E}\right)$, 15.v.14, mango orchard, coll. Srinivas (NPC), Medahatti: $9 \bigcirc^{\top}$ and 13 ,,$\left(13^{\circ} 43^{\prime} 60 \mathrm{~N}, 75^{\circ} 19^{\prime}\right.$
60E, 600msl), mango orchard, coll. Srinivas (NPC).

\section{Remarks}

Idioscopus nitidulus is distinguished from $I$. clypealis with face irregularly marked with brown or black patches without well-defined black spot.

Idioscopus spectabilis Viraktamath 1979: 23 [Fig: 12, 24, 36]

\section{Male}

Overall brown to yellow in colour, face yellow, two round spot on upper surface of face absent. Ocelli yellow, area between and above ocelli with irregular pattern. Lateral spot on the eye. Genae median with irregular black spot.

Pronotum yellowish with median dark patch more or less circular (discal spot). Scutellum completely demarketed into yellow apical and basal black. Forewing with claval area lemon yellow in colour [Fig: 12 (23, 24), 24(23, 24)].

\section{Male genitalia [Fig: 36]}

Pygofer elongated, well developed apodemes on anterior margin with anal collar processes medially [Fig: 36 (o)]. Subgenital plate elongated, setae start from $2 / 3^{\text {rd }}$ basally both side and extended to apically and sparsely [Fig: 36 (n)]. Connective T shape with broad supporting base [Fig: $36(\mathrm{p})$ ].

Style strongly curved, 3times the length from attachment from base to connective, narrowed in middle with strong spine like setae in apex [Fig: 36 (n)]. Aedeagus in inverted S shape, preatrium elongated, shaft strongly curved and narrowed apical [Fig: 36 (m)] and valve [Fig: $36(\mathrm{q})$ ]. 


\section{Measurments (mm)}

Male 1.9 length, pronotum 0.2 length 0.5 width, scutellum 0.3 length, 0.4 width. Crown 0.1 length and 0.7 wide across the eyes, distance between compound eye and ocelli 0.1 and 0.1 length of clypeus and distance between ocelli 0.1 . Female 1.2 length and 0.1 length of crown.

\section{Material examined}

$10^{\lambda}$ and 1ㅇ, INDIA: Karnataka: Coorg: Makuta: $\left(12^{\circ} 04^{\prime} \mathrm{N}, 7^{\circ} .43^{\prime} \mathrm{E}, 909 \mathrm{msl}\right)$, 05.v.2005, Vateriaindica. Canopy, coll. Y.B. Srinivas (NPC)

\section{Remark}

Idioscopus spectabilis is distinguished by presence of discal spoton the pronotum from Idioscopus dworakowskae.

\section{Acknowledgement}

Author gratefully acknowledges, Dr. Naresh M. Meshram, Division of Entomology IARI, New Delhi for his support in preparation of manuscript.

\section{References}

Das, N.M., Ramamany KS and Nair MRGK. Biology of a new jassid of mango Amrascasplendens Ghauri. Indian Journal of Entomology, 1969; 33:288290.

Dietrich, C.H. Phylogeny of the leafhopper subfamily: Evacanthinae with a review of neotropical species and notes on related groups (Hemiptera: Membracoidea: Cicadellidae). Systematic Entomology, 2004; 29: 455487.

Knight, W.J. Techniques for use in the identification of leafhoppers (Homoptera: Cicadellidae). Entomologist's Gazette, 1965; 16: 12936.

Oman, P.W. The Nearctic leafhoppers (Homoptera: Cicadellidae). A genericclassification and checklist. Memoirs of the Entomological Society of Washington. 1949; 3: 1-253.

Pena, J.E., Mohyuddin AI Wysoki M. A review of the pest management situation in mango agroecosystem. Phytoparasitica, 1998; 26: 1-20.

Viraktamath, C.A. Auchenorrhyncha (Homoptera) associated with mango, Mangifera indica L. Tropical Pest Management, 1989; 35: 431-434.

Viraktamath, S., Viraktamath CA. New species of Busoniominus and Idioscopus (Homoptera, Cicadellidae: Idiocerinae) breeding on mango in south India. Entomon, 1985; 10 (4): 305 - 311.

Viraktamath, S.A., Viraktamath, CA. The Leafhoppers (Homoptera: Cicadelidae) and their host plants in Karnataka. Karnataka jounal of agricultural sciences, 1995:8(2):249-255.

Viraktamath, C.A. New genera and species of idiocerine leafhoppers (Hemiptera: Cicadellidae) from India, Sri Lanka and Myanmar. Biosystematica, 2007; 1 (1): $21-30$.

\section{How to cite this article:}

Srinivasa, N., N. Ramya and Naresh M. Meshram. 2017. Taxonomic Studies of Leafhoppers (Hemiptera: Cicadellidae) Fauna Associated with Mango from India. Int.J.Curr.Microbiol.App.Sci. 6(10): 2108-2124. doi: https://doi.org/10.20546/ijcmas.2017.610.251 